\title{
Determination of Changes in the Mechanical and Color Properties of Some Wood Species Treated with Shellac
}

\author{
Eser Sözen
}

The properties of wood, which is a natural and sustainable substance, change under biotic and abiotic factors. Different methods along with chemical/natural substances are used to extend the service life of wood and increase its performance under different conditions. Shellac is a natural product secreted by insects onto host trees. It is used extensively as a coating, especially in the food and pharmaceutical industries. Its natural properties and biocompatibility increase the areas where it is used. This study investigated the effects on the physical and mechanical properties of pine, beech, and fir species impregnated with shellac solutions at different concentrations (1\%,3\%, and 5\%) and sodium hydroxide $(\mathrm{NaOH})$. The study found that $10 \% \mathrm{NaOH}$ solution caused significant decreases in the bending strength values. The highest bending strength values were obtained for the Scots pine and fir woods at $5 \%$ shellac concentration and for the beech wood at $1 \%$ concentration. The highest modulus of elasticity (MOE) values were reached at $1 \%$ shellac concentration in all three tree species. Although the lightness $\left(L^{*}\right)$ of the wood samples decreased with shellac impregnation, the chromatic coordinate $\left(a^{*}\right.$ and $\left.b^{*}\right)$ values increased. According to the Fouriertransform infrared (FTIR) spectroscopy results, changes were determined in the chemical structures of the wood samples impregnated with $\mathrm{NaOH}$, whereas the shellac did not cause a change in the chemical structure of the wood samples.

DOI: 10.15376/biores.17.1.1703-1716

Keywords: Shellac; Wood; Mechanical properties; FTIR; Color change

Contact information: Bartin University, Faculty of Forestry, Department of Forest Industrial Engineering, 74200, Bartın,Turkey; E-mail: esozen@bartin.edu.tr

\section{INTRODUCTION}

Wood is an essential and valuable natural resource. It plays a significant role in human activities with its use in construction, furniture, and many other products. However, wood is subject to degradation by natural organisms and abiotic factors. When wood is exposed to moisture and outdoor conditions, fungi and insects consume the lignocellulosic compounds found in wood. This situation causes significant changes in the physical and mechanical properties of wood (Wong et al. 2014). A $10 \%$ weight loss in wood caused by fungi leads to a $50 \%$ reduction in wood strength properties (Ross 2010). For this reason, many different applications of wood preservation methods have been developed to reduce these negative effects at affordable costs, to extend the service life of wood products, and to use wood in a more efficient manner (Yin et al. 2017; Teng et al. 2018).

Shellac is a unique natural resin secreted by certain insect species (e.g. Kerria lacca). The chemical composition of shellac depends on the type of host tree, the insect species, and the refining method. It is widely used as a protective coating or brightener in 
the food industry and as an enteric coating in the pharmaceutical industry. Shellac is environmentally friendly and has a variety of uses. However, the use of shellac is still limited due to the mechanical fragility and poor stability caused by the polymerization reactions that occur within it (Bar and Bianco-Peled 2020). Structurally, shellac is a low molecular weight resin consisting mainly of oxyacid polyesters. Oxyacids are divided into aleuritic acids and cyclic terpene acids, which are connected by ester bonds, which, respectively, make up the hydrophobic and hydrophilic components of shellac (Luo et al. 2016). Therefore, shellac has the extra advantage of exhibiting excellent amphiphilicity, in comparison to other natural polymers (Patel et al. 2013). Shellac has a low vapor permeability, good adhesion, and a high gloss. Shellac is inexpensive and it has excellent film forming properties. However, shellac has poor water resistance. Shellac is biocompatible and can be cured at room temperature (Luangtana-Anan et al. 2017).

The use of shellac in many industrial areas has increased in recent years. Shellac used in wood modification processes can be used for the protection of damaged wood (Reinprecht 2011), biological resistance of wood (Remadevi et al. 2015) and surface treatments (Jankowska and Szczęsna 2011). It is especially preferred to create a glossy film layer in musical instruments where high gloss is required (Licchelli et al. 2013). Liu et al. (2020a) investigated the color and dimensional stability in wood using linseed oil and shellac. Ethanol was used in the preparation of the solution and the weight percentage gain (WPG) ratio was reported to be $21.7 \%$ for linseed oil and $19 \%$ for shellac. The study reported no significant difference in the $L^{*}, a^{*}$, and $b^{*}$ values compared to the control samples. In the dimensional stabilization, the samples with shellac showed $21.8 \%$ and $16.7 \%$ lower swelling properties compared to the control samples in the transverse and radial directions, respectively. In another study, Liu et al. (2020b) investigated the dimensional stabilization of shellac-treated wood, its physicochemical structures, and its thermostability. As a result of the Fourier-transform infrared (FTIR) analysis, they reported that the number of hydroxyl groups contributing to the $3400 \mathrm{~cm}^{-1}$ absorbance band decreased, which increased the dimensional stability. Yan et al. (2021) examined the properties of shellac used in the microencapsulation process. They evaluated the effects of the solutions on linden wood and reported that the elongation at break and gloss values were the highest for the solutions prepared at $600 \mathrm{rpm}$ using 5\% shellac.

Shellac, which is a natural, sustainable, and biocompatible product, is used extensively in the food, drug, and cosmetics sectors. Its use is quite new in the wood protection industry and is concentrated in certain areas such as dimensional stabilization. The main aim of this study was to determine the changes in the bending, elasticity modulus, and color of Scots pine (Pinus sylvestris), beech (Fagus orientalis), and fir (Abies bornmülleriana) wood impregnated with shellac in sodium hydroxide $(\mathrm{NaOH})$ solution. In addition, the chemical changes in the samples were determined by FTIR analysis.

\section{EXPERIMENTAL}

\section{Materials}

The shellac used in the study was in the form of flakes. The color of the shellac differs according to the insect species and the refining method. The most preferred colors are gold, lemon, and white. The gold-colored shellac flakes that were used in the study are shown in Fig. 1. 


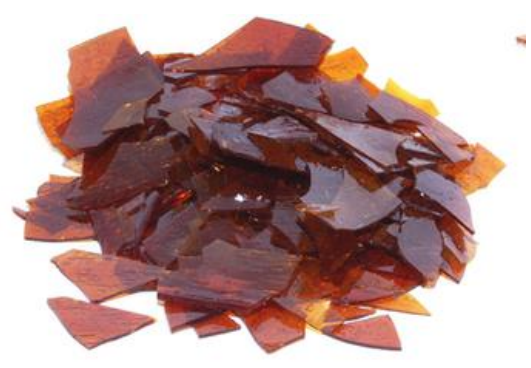

Fig. 1. Shellac flakes

The solvents that are used to dissolve shellac include ethanol (Chen et al. 2018), spirit (mineral spirit) (Ghosh et al. 2015), and sodium hydroxide ( $\mathrm{NaOH})$ (Mei et al. 2018). Sodium hydroxide was chosen for this study because it is cheap and easily accessible. Beech (Fagus orientalis Lipsky) wood, which is widely used in furniture production, and Scots pine (Pinus sylvestris L.) and fir (Abies bornmülleriana Mattf.) woods, which are used in construction and wooden structures, were selected for the study. The wood samples were obtained from timber free of knots, fungi, insects, and fiber curl. The air-dry and oven-dry density values of the wood samples that were used in the study are given in Table 1.

Table 1. Air-dry and Oven-dry Density Values of the Wood Samples

\begin{tabular}{|c|c|c|}
\hline Wood Type & $\begin{array}{c}\text { Air-dry Density } \\
\left(\mathbf{g} / \mathbf{c m}^{\mathbf{3}}\right)\end{array}$ & $\begin{array}{c}\text { Oven-dry Density } \\
\left(\mathbf{g} / \mathbf{c m}^{\mathbf{3}}\right)\end{array}$ \\
\hline Scots pine & 0.51 & 0.47 \\
\hline Beech & 0.69 & 0.60 \\
\hline Fir & 0.46 & 0.39 \\
\hline
\end{tabular}

\section{Methods}

Within the scope of the study, $4 \mathrm{~kg}$ of $10 \%$ (g:g) $\mathrm{NaOH}$ solution was prepared. This solution was then divided into four 1-L beakers. The shellac was added to three of these solutions at a level of $1 \%, 3 \%$ and $5 \%(\mathrm{~g}: \mathrm{g})$ and mixed with a magnetic stirrer for $10 \mathrm{~min}$. A 1-L $10 \% \mathrm{NaOH}$ solution without shellac was prepared for comparison with the samples that were impregnated with shellac. Since $\mathrm{NaOH}$ affects components in the structure of wood such as lignin, in this case, it was considered more appropriate to compare the performance of the samples treated with shellac with the samples that were treated with $10 \% \mathrm{NaOH}$ only and not with the untreated (control) samples. The tests of the untreated control samples were carried out for use in the overall assessment.

The wood samples were kept in a climate cabinet for one week at $65 \%$ relative humidity and $25^{\circ} \mathrm{C}$ temperature before they were impregnated with the prepared solutions. Prior to the impregnation, the wood samples were dried in an oven at $103^{\circ} \mathrm{C}$ until a constant weight was reached. The air-dried samples were treated with dilute solutions in an impregnation chamber according to the fullcell process. In this process, the samples were first left under vacuum at $650 \mathrm{~mm} / \mathrm{Hg}$ for $30 \mathrm{~min}$, followed by atmospheric pressure for 60 min. The weight gain $(\%)$ for each compound was calculated based on the initial $(M u)$ and final $(M t)$ weight of each wood sample using Eq. 1,

$$
W P G(\%)=100\left[\frac{M t-M u}{M u}\right]
$$

The bending strength tests were carried out on all the wood samples with the 
dimensions of $10 \mathrm{~mm} \times 10 \mathrm{~mm} \times 200 \mathrm{~mm}$, as specified in the DIN 52186 (1978) standard. For the static bending strength and the modulus of elasticity (MOE) values that were determined by the three-point bending strength, the distance between the supports was applied as $150 \mathrm{~mm}$. The load in the elastic region (F2-F1) and the difference of the deformation amounts corresponding to these loads (d2-d1) were taken for the calculation of the MOE. Care was taken to ensure that these values were between $10 \%$ and $40 \%$ of the maximum load. The bending strength $\left(\sigma_{B}\right)$ and the $\operatorname{MOE}\left(\sigma_{M O E}\right)$ values of the samples were calculated using Eq. 2 and 3, respectively,

$$
\begin{aligned}
& \sigma_{B}=\frac{3}{2} \frac{F \cdot L_{S}}{b \cdot h^{2}} \\
& \sigma_{M O E}=\frac{\Delta F \cdot L_{S}^{3}}{4 . \Delta d \cdot b \cdot h^{3}}
\end{aligned}
$$

where $F$ is the maximum load value $(\mathrm{N}), L_{s}$ is the distance between the supports $(150 \mathrm{~mm})$, $b$ is the width of the sample $(10 \mathrm{~mm}), h$ is the height of the sample $(10 \mathrm{~mm}), \Delta F$ is the difference of the two loads within the elastic limits, and $\Delta d$ is the deformation difference corresponding to the two loads within the elastic limits (10\% to $40 \%$ of maximum load).

The color was measured using the Konica Minolta CD-600 color measuring device (Tokyo, Japan) in accordance with the ISO 7724-2 (1984) standard. Ten wood samples were used for each variation and three measurements were made from each sample. The CIELab (Commission International de i'Eclairage) system consists of three variables (ISO 7724-2 1984). $L^{*}$ is the light stability and $a^{*}$ and $b^{*}$ denote the chromatic coordinates $\left(+a^{*}\right.$ for red, $-a^{*}$ for green, $+b^{*}$ for yellow, $-b^{*}$ for blue).

The FTIR measurements were performed using a PerkinElmer Spectrum 100 FTIR spectroscopy device (Waltham, MA, USA). Accordingly, the solid measurements were made from the surface without degrading the samples by using the PIKE ATR Diamond / ZnSe apparatus (Madison, WI, USA). The spectrum of each sample had a resolution of 4 $\mathrm{cm}^{-1}$, and they were taken in the scanning range of 700 to $4000 \mathrm{~cm}^{-1}$. The spectral measurements were taken from five different points on the samples. For each variation, a single spectrum was obtained by calculating the average of the spectra programmed in the device.

\section{Evaluation of Data}

The one-way analysis of variance (ANOVA) included in the Statistical Package for the Social Sciences (SPSS) 16.0 (Chicago, IL, USA) was used to evaluate the bending strength and the MOE data. Duncan's test was applied to determine the differences between the groups.

\section{RESULTS AND DISCUSSION}

Within the scope of the study, the weight percentage gain (WPG) values were calculated according to Eq.1 for each variation that was subjected to the impregnation process. The WPG and standard deviation (SD) values of the samples are provided in Table 2 .

The weight gain values of the Scots pine, beech, and fir samples that were impregnated with $10 \% \mathrm{NaOH}$ were $28.32 \%, 25.56 \%$, and $18.91 \%$, respectively. The Scots pine and beech samples showed similar weight gain values, whereas lower weight gain values were obtained with the fir wood samples. The weight gain values obtained after 
dissolving the shellac polymer at different concentrations in $10 \% \mathrm{NaOH}$ were lower than the weight gain values of the samples impregnated with $\mathrm{NaOH}$ alone. Table 3 shows that when the shellac concentration was increased, the weight gain values decreased, except for the beech impregnated with 5\% shellac. The highest weight gain was obtained with $1 \%$ shellac. In another study (Liu et al. 2020b), a weight gain of $13.01 \%$ was obtained with a solution prepared with a $20 \%$ concentration of ethyl alcohol. Compared with other published studies (Liu et al. 2020a, b), the preparation of shellac polymer with $\mathrm{NaOH}$ at lower concentrations ( $1 \%$ to $5 \%$ ) in this study was shown to increase the weight gain values in the wood samples.

Table 2. The Ratios and Weights of the Board Variations in the Study

\begin{tabular}{|c|c|c|}
\hline \multicolumn{2}{|c|}{ Variations } & WPG /SD \\
\hline \multirow{4}{*}{ Scots Pine } & $10 \% \mathrm{NaOH}$ & $28.32(2.52)$ \\
\cline { 2 - 3 } & $1 \%$ Shellac & $24.41(5.05)$ \\
\cline { 2 - 3 } & $3 \%$ Shellac & $8.03(2.29)$ \\
\cline { 2 - 3 } & $5 \%$ Shellac & $1.85(1.24)$ \\
\hline \multirow{4}{*}{ Beech } & $10 \%$ NaOH & $25.56(3.48)$ \\
\cline { 2 - 3 } & $1 \%$ Shellac & $23.63(1.42)$ \\
\cline { 2 - 3 } & $3 \%$ Shellac & $8.06(2.13)$ \\
\cline { 2 - 3 } & $5 \%$ Shellac & $13.33(1.71)$ \\
\hline \multirow{3}{*}{ Fir } & $10 \%$ NaOH & $18.91(2.63)$ \\
\cline { 2 - 3 } & $1 \%$ Shellac & $12.76(1.64)$ \\
\cline { 2 - 3 } & $3 \%$ Shellac & $1.64(0.57)$ \\
\cline { 2 - 3 } & $5 \%$ Shellac & $1.83(0.65)$ \\
\hline
\end{tabular}

\section{Mechanical Properties}

The bending strength values of the control samples of Scots pine, beech, and fir woods were determined to be $87.0,117.5$ and $79.9 \mathrm{~N} / \mathrm{mm}^{2}$, respectively. The data obtained were compatible with the relevant literature. Percin et al. (2016) determined the bending strength values to be $124.4 \mathrm{~N} / \mathrm{mm}^{2}$ in untreated beech woods.

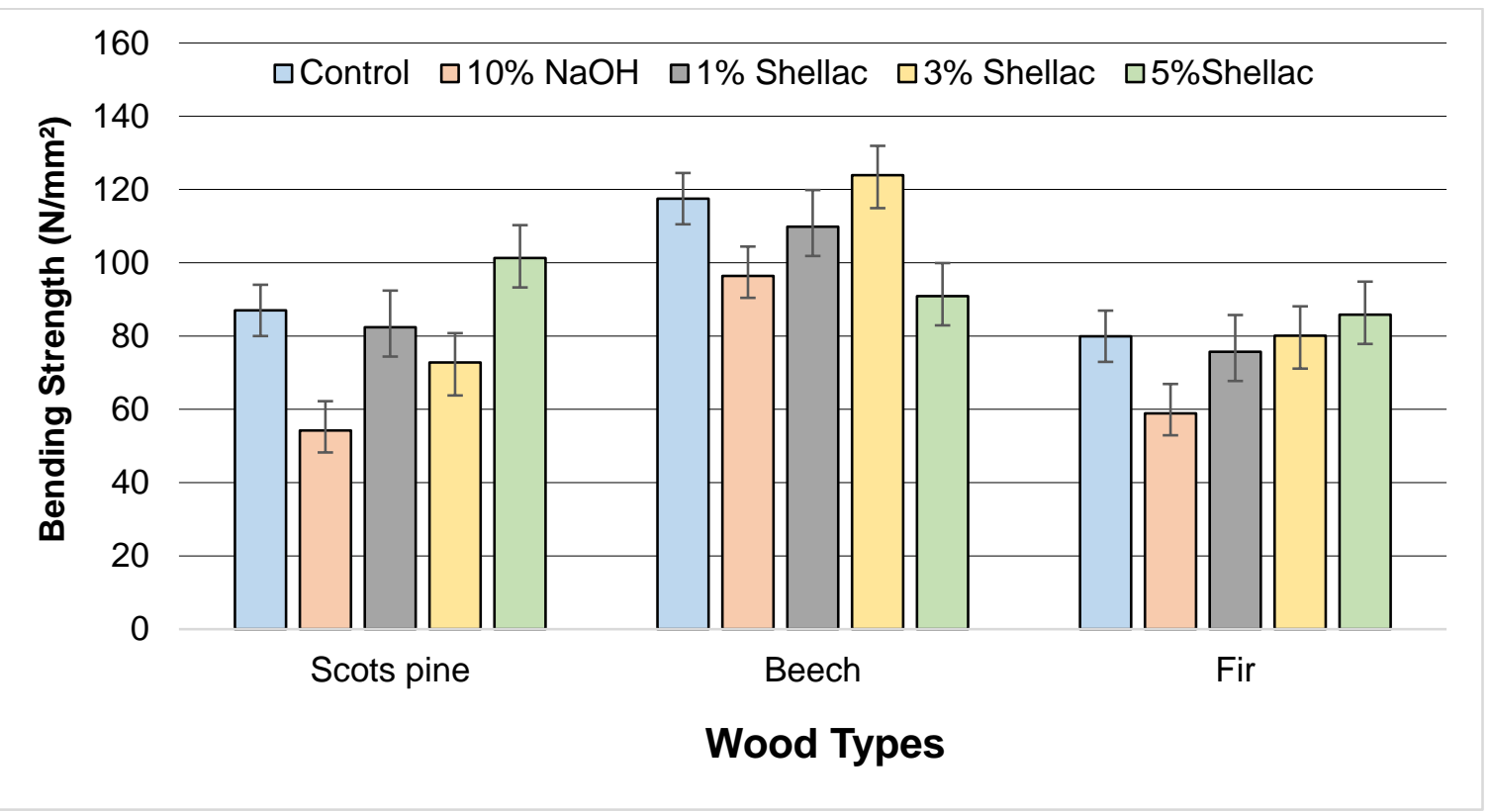

Fig. 2. Bending strength and standard deviation values of the samples 
In a study on Scots pine, Kamperidou et al. (2014) determined the bending strength of Scots pine wood to be $81.4 \mathrm{~N} / \mathrm{mm}^{2}$. Zeidler et al. (2015) found the bending strength of fir wood to be $78.1 \mathrm{~N} / \mathrm{mm}^{2}$. Figure 2 shows the bending strength and standard deviation values of the samples that were prepared in this study.

The bending strength values decreased in the samples impregnated with $10 \% \mathrm{NaOH}$ alone at the rates of $37.6 \%, 17.9 \%$, and $26.2 \%$ in the Scots pine, beech, and fir wood species, respectively.

Sodium hydroxide is a simple chemical that can swell cellulose at a certain concentration, or even dissolve cellulose at high concentrations. Soda hydrates cause dissolution and can penetrate the amorphous area of the cellulose and break up the adjacent crystalline regions. It was determined that in soda solutions the maximum solubility for the degree of polymerization (DP) of cellulose can be achieved using $8 \%$ to $10 \%$ soda solution (Isogai and Atalla 1998). In addition to this, $\mathrm{NaOH}$ alone has never been used as a solvent to dissolve cellulose in industrial applications due to problems with the cellulose such as chemical degradation, high soda concentration, and chemical recovery (Wang et al. 2008). In their study examining the structural changes caused by $\mathrm{NaOH}$ in wood at different temperatures, Shi et al. (2018) reported that the increase in temperature (80, 100, and 120 ${ }^{\circ} \mathrm{C}$ ) increased the degradation of the cell wall. The chemical composition that is most often found in wood cell walls after cellulose is lignin. It binds to cell wall polysaccharides by covalent and non-covalent interactions. It ensures the structural integrity of the cell walls, which is very important for woody plants (Tiimonen 2007). Cell walls define the morphology and size of individual cells and, ultimately, the properties of wood (O'Neill and York 2003) and provide resistance to tensile strength (Obembe 2006). Lignin fills the gaps between the composition of cellulose, hemicellulose and pectin in the cell wall and increases the mechanical strength of the cell wall (Janssen 2000). In this study, the samples treated with $10 \% \mathrm{NaOH}$ showed lower bending strength values compared to the control samples because of the degradation of lignin in the cell wall. On the other hand, acids such as abietic acid in the shellac content may have neutralized $\mathrm{NaOH}$ and caused a decrease in the negative effects on wood.

The bending strength values of the woods that were treated with $1 \%$ shellac decreased as in the samples treated with $10 \% \mathrm{NaOH}$. However, these decreases were less than what was seen in the samples treated with $10 \% \mathrm{NaOH}$. The bending strength values of the Scots pine, beech, and fir woods treated with $1 \%$ shellac decreased by $5 \%, 6.6 \%$, and $5.25 \%$, respectively, compared to the control samples. On the other hand, increases in the bending strength values were observed when compared to the samples treated with only $10 \% \mathrm{NaOH}$. The bending strength value of the Scots pine wood treated with $3 \%$ shellac decreased by $16.3 \%$ compared to the control samples. The highest bending strength value $\left(123.9 \mathrm{~N} / \mathrm{mm}^{2}\right.$ in beech wood) was obtained in samples that were treated with $3 \%$ shellac. There was no significant difference between the bending strength value of the fir wood control samples $\left(79.9 \mathrm{~N} / \mathrm{mm}^{2}\right)$ and that of the samples that were treated with $3 \%$ shellac $\left(80.1 \mathrm{~N} / \mathrm{mm}^{2}\right)$. The highest bending strength values of the Scots pine and fir wood were obtained in the variations treated with $5 \%$ shellac, at $101 \mathrm{~N} / \mathrm{mm}^{2}$ and $85.9 \mathrm{~N} / \mathrm{mm}^{2}$, respectively. Compared to the control samples, these values corresponded to an increase of $16 \%$ and $7.4 \%$, respectively. Although the 5\% shellac concentration imparted the highest bending strength in the Scots pine and fir samples, it imparted the lowest value (90.9 $\mathrm{N} / \mathrm{mm}^{2}$ ) in the beech wood. High concentration shellac applications were found to be unsuitable for beech wood, which reached the highest bending strength $\left(123.9 \mathrm{~N} / \mathrm{mm}^{2}\right)$ at a $3 \%$ concentration. An increase was obtained in the samples treated with shellac compared 
to the samples treated with $10 \% \mathrm{NaOH}$ alone. However, these increases did not increase proportionally to the rate of shellac. The anatomical structure of the woods and the soluble shellac ratios were effective in the formation of these differences. In order for the shellac to absorb in the wood, it should penetrate as much as possible. This differs according to the density properties of the wood and the structure of the cell walls (the passages in the cell walls). On the other hand, the chemical formula of shellac $\left(\mathrm{C}_{30} \mathrm{H}_{50} \mathrm{O}_{11}\right)$ is compatible with bonding with the chemical structure of wood. Especially the $\mathrm{CH}, \mathrm{OH}$ structures of aleuritic acid have the potential to bond with carbon and hydroxyl groups in wood.

Density is one of the most important factors that affect the mechanical properties of wood. The structures that make up the density in wood are the walls of the trachea cells in deciduous trees and the tracheid cells in coniferous trees. On the other hand, cell walls have a different anatomical structure depending on where they are located in the earlywood or latewood. The cell wall has a large effect in high-density beech wood, which exhibits correspondingly high bending strength values. Beech wood is anatomically in the group of scattered-ringed woods, a situation that creates a higher cell wall ratio per unit area. According to Panov et al. (2010), the pits in the cell wall allow moisture to pass between the cells. These pits play the same role in the impregnation processes. Shellac dissolved with $\mathrm{NaOH}$ can reach the cell walls with the effect of vacuum-pressure. The shellac, which clings to the cell wall by removing the water after impregnation, provides support to the wood. This phenomenon may explain the higher bending strength values that were observed for the samples that were treated with shellac.

From the bending test results, the one-way ANOVA test determined that there was a significant difference $(p<0.05)$ between the variations of beech, Scots pine, and fir woods. The groups formed by the variations were revealed by Duncan's test and are shown in Table 3.

Table 3. Duncan's Test Results According to the Wood Types

\begin{tabular}{|c|c|c|c|c|c|c|c|c|c|c|c|}
\hline \multicolumn{4}{|c|}{ Beech } & \multicolumn{5}{c|}{ Scots pine } & \multicolumn{3}{c|}{ Fir } \\
\hline \multirow{2}{*}{ Sample } & \multicolumn{3}{|c|}{ Groups } & Sample & \multicolumn{3}{c|}{ Groups } & Sample & \multicolumn{2}{c|}{ Groups } \\
\cline { 2 - 12 } & $\mathbf{1}$ & $\mathbf{2}$ & $\mathbf{3}$ & & $\mathbf{1}$ & $\mathbf{2}$ & $\mathbf{3}$ & $\mathbf{4}$ & & $\mathbf{1}$ & $\mathbf{2}$ \\
\hline $\begin{array}{c}5 \% \\
\text { Shellac }\end{array}$ & 90.90 & & & $\begin{array}{c}10 \% \\
\mathrm{NaOH}\end{array}$ & 54.23 & & & & $\begin{array}{c}10 \% \\
\mathrm{NaOH}\end{array}$ & 58.92 & \\
\hline $\begin{array}{c}10 \% \\
\mathrm{NaOH}\end{array}$ & 96.43 & & & $\begin{array}{c}3 \% \\
\text { Shellac }\end{array}$ & & 72.79 & & & $\begin{array}{c}1 \% \\
\text { Shellac }\end{array}$ & & 75.74 \\
\hline $\begin{array}{c}1 \% \\
\text { Shellac }\end{array}$ & 109.85 & & $\begin{array}{c}1 \% \\
\text { Shellac }\end{array}$ & & & 82.40 & & Control & & 79.94 \\
\hline Control & 117.51 & 117.51 & Control & & & 87.00 & & $\begin{array}{c}3 \% \\
\text { Shellac }\end{array}$ & & 80.11 \\
\hline $\begin{array}{c}3 \% \\
\text { Shellac }\end{array}$ & & & 123.91 & $\begin{array}{c}5 \% \\
\text { Shellac }\end{array}$ & & & & 101.00 & $\begin{array}{c}5 \% \\
\text { Shellac }\end{array}$ & & 85.90 \\
\hline
\end{tabular}

According to Duncan's test results, the impregnation of the fir wood with shellac did not have a significant impact on the bending strength of the wood. The Scots pine wood samples with 5\% shellac had the highest bending strength value, whereas the beech wood samples with 5\% shellac had the lowest bending strength value. It was clear that the $10 \%$ $\mathrm{NaOH}$ solution had reduced the bending strength values.

When the MOE values in bending were examined, the control sample values for the Scots pine, beech, and fir woods were determined to be 6375,8869 , and $7245 \mathrm{~N} / \mathrm{mm}^{2}$, respectively (Fig. 3). 


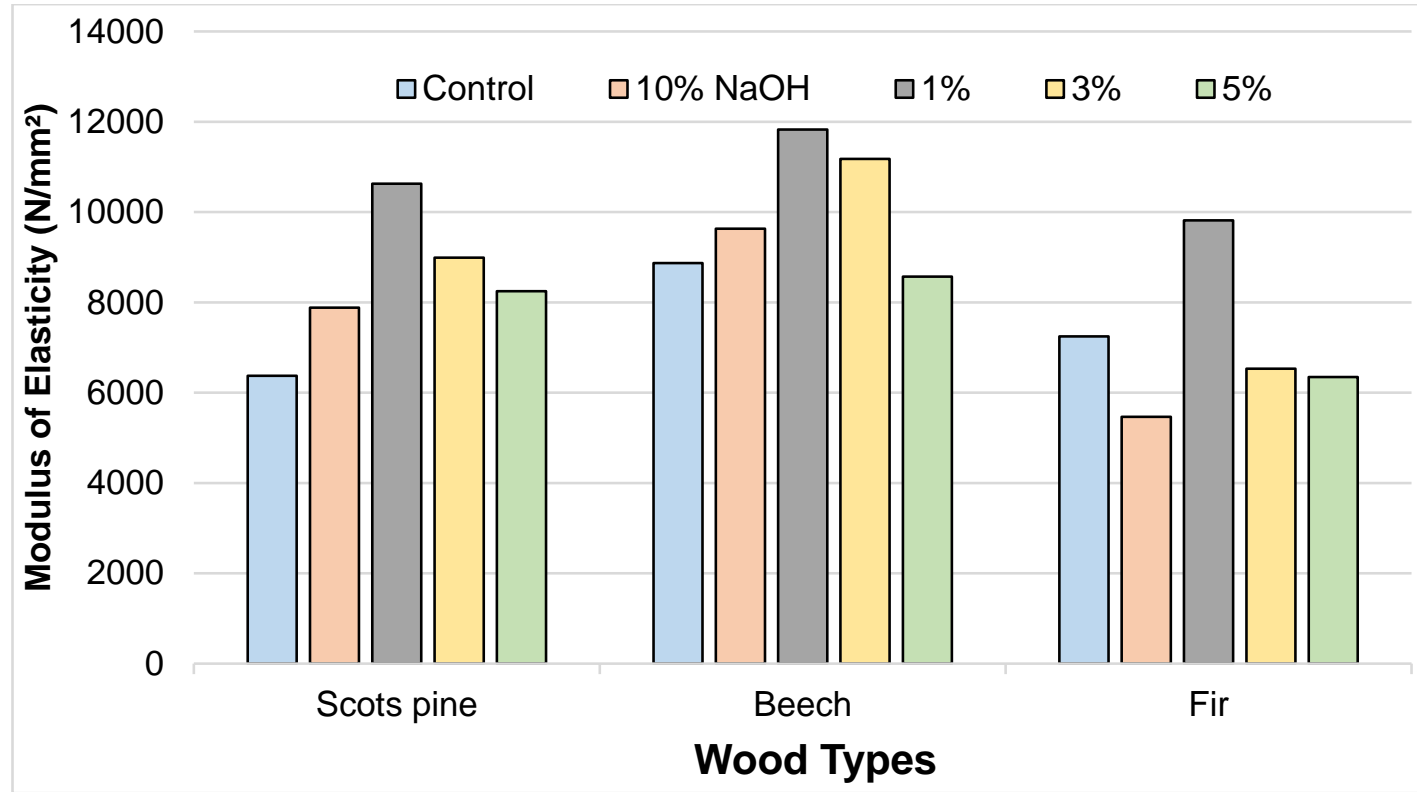

Fig. 3. MOE values of the samples

The highest MOE values in all the wood samples were obtained for those impregnated with the $1 \%$ concentration of shellac. Compared to the control samples, the highest MOE increase was observed in the fir (50\%), followed by the Scots pine (45\%), and the beech $(27 \%)$ woods. The increase in the concentration ratio after $1 \%$ caused the MOE values to decrease. While the $10 \% \mathrm{NaOH}$ treatment caused the bending strength values to decrease, the MOE values increased between $2 \%$ and $7.7 \%$ compared to the control samples. In other studies, it was reported that the MOE value increased in alkaline treatments with $\mathrm{NaOH}$ (Chandrasekar et al. 2017; Negawo et al. 2019). In this study, the increase in the MOE values in the samples that were impregnated with shellac was attributed to the softening of the lignin in the cell wall by the $\mathrm{NaOH}$.

\section{Color Changes}

The color change values in the test and control samples were calculated using $L^{*}$ (light intensity), $a^{*}$, and $b^{*}$ chromatic coordinates $\left(+a^{*}\right.$ red, $-a^{*}$ green, $+b^{*}$ yellow, and $b^{*}$ blue) determined according to the CIELab system. Table 4 shows the $L^{*}, a^{*}$, and $b^{*}$ values and the standard deviations in parenthesis of the sample groups.

The $L^{*}$ values of the control samples were 81.8 for the Scots pine, 71.4 for the beech, and 83.6 for the fir. After the wood samples were impregnated with $10 \% \mathrm{NaOH}$, the surface of the samples darkened and the $L^{*}$ value was $25.2 \%$ in the Scots pine samples, $24.0 \%$ in the beech samples, and $24.9 \%$ in the fir samples. The reduced $L^{*}$ values of the wood samples were improved with the shellac impregnation. However, no difference was observed between the concentrations. The $a^{*}$ and $b^{*}$ values increased after the impregnation processes using only $10 \% \mathrm{NaOH}$ and shellac. The $a^{*}$ and $b^{*}$ represent the chromatic coordinates ( $+a^{*}$ for red, $-a^{*}$ for green, $+b^{*}$ for yellow, and $-b^{*}$ for blue). $10 \%$ sodium hydroxide alone had a significant effect on $L^{*}, a^{*}, b^{*}$ values. In $\mathrm{NaOH}$ samples containing shellac, these changes (decrease) continued in the same direction, but the amount of factor is less. Natural or chemically formed/created degradations in wood cause color change in wood. Pastore et al. (2004), reported that the degradation in wood was due to the quinones found on the surface. 
Table 4. The Color Values $\left(L^{*}, a^{*}, b^{*}\right)$ of the Test and Control Samples

\begin{tabular}{|c|c|c|c|c|}
\hline \multicolumn{1}{|c|}{} & $\boldsymbol{L}^{*}$ & $\boldsymbol{a}^{*}$ & $\boldsymbol{b}^{\boldsymbol{*}}$ \\
\hline \multirow{4}{*}{ Scots Pine } & Control & $81.77(2.90)$ & $6.18(1.09)$ & $23.48(1.60)$ \\
\cline { 2 - 5 } & $10 \%$ NaOH & $61.14(2.22)$ & $11.72(0.52)$ & $38.26(1.43)$ \\
\cline { 2 - 5 } & $1 \%$ Shellac & $55.07(0.87)$ & $13.04(0.55)$ & $35.16(0.56)$ \\
\cline { 2 - 5 } & $3 \%$ Shellac & $53.08(0.66)$ & $10.75(0.74)$ & $29.53(0.68)$ \\
\cline { 2 - 5 } Beech & $5 \%$ Shellac & $51.95(1.39)$ & $13.90(0.13)$ & $28.52(0.74)$ \\
\hline & Control & $71.45(3.43)$ & $7.54(1.34)$ & $15.76(2.21)$ \\
\cline { 2 - 5 } & $10 \%$ NaOH & $54.30(0.95)$ & $10.91(0.44)$ & $31.22(0.82)$ \\
\cline { 2 - 5 } & $1 \%$ Shellac & $43.52(2.88)$ & $10.67(0.67)$ & $20.30(3.82)$ \\
\cline { 2 - 5 } & $3 \%$ Shellac & $47.17(1.65)$ & $11.30(1.76)$ & $23.54(1.86)$ \\
\cline { 2 - 5 } & $5 \%$ Shellac & $46.96(0.78)$ & $11.73(0.42)$ & $22.78(0.83)$ \\
\hline \multirow{5}{*}{ Fir } & Control & $83.55(2.54)$ & $3.87(0.45)$ & $15.76(2.21)$ \\
\cline { 2 - 5 } & $10 \%$ NaOH & $62.77(1.30)$ & $9.19(0.34)$ & $35.94(1.65)$ \\
\cline { 2 - 5 } & $1 \%$ Shellac & $57.36(1.93)$ & $12.53(0.67)$ & $34.43(1.04)$ \\
\cline { 2 - 5 } & $3 \%$ Shellac & $55.71(2.53)$ & $10.86(1.10)$ & $28.94(1.74)$ \\
\cline { 2 - 5 } & $5 \%$ Shellac & $55.92(2.32)$ & $11.93(0.38)$ & $26.87(1.11)$ \\
\hline
\end{tabular}

\section{FTIR Analysis}

The FTIR analysis was performed on the test and control samples by scanning in the wave range of 4000 to $700 \mathrm{~cm}^{-1}$. The regions where the modification process is most intense in wood material are found between $1800 \mathrm{~cm}^{-1}$ and $700 \mathrm{~cm}^{-1}$ and are referred to as "fingerprints". These absorption peaks reflect the changes in the benzene rings, the main lignin and carbohydrate functional groups, and the change in the crystalline and amorphous content of cellulose. The FTIR graphs of the test and control samples are given in Figs. 4 through 6 .

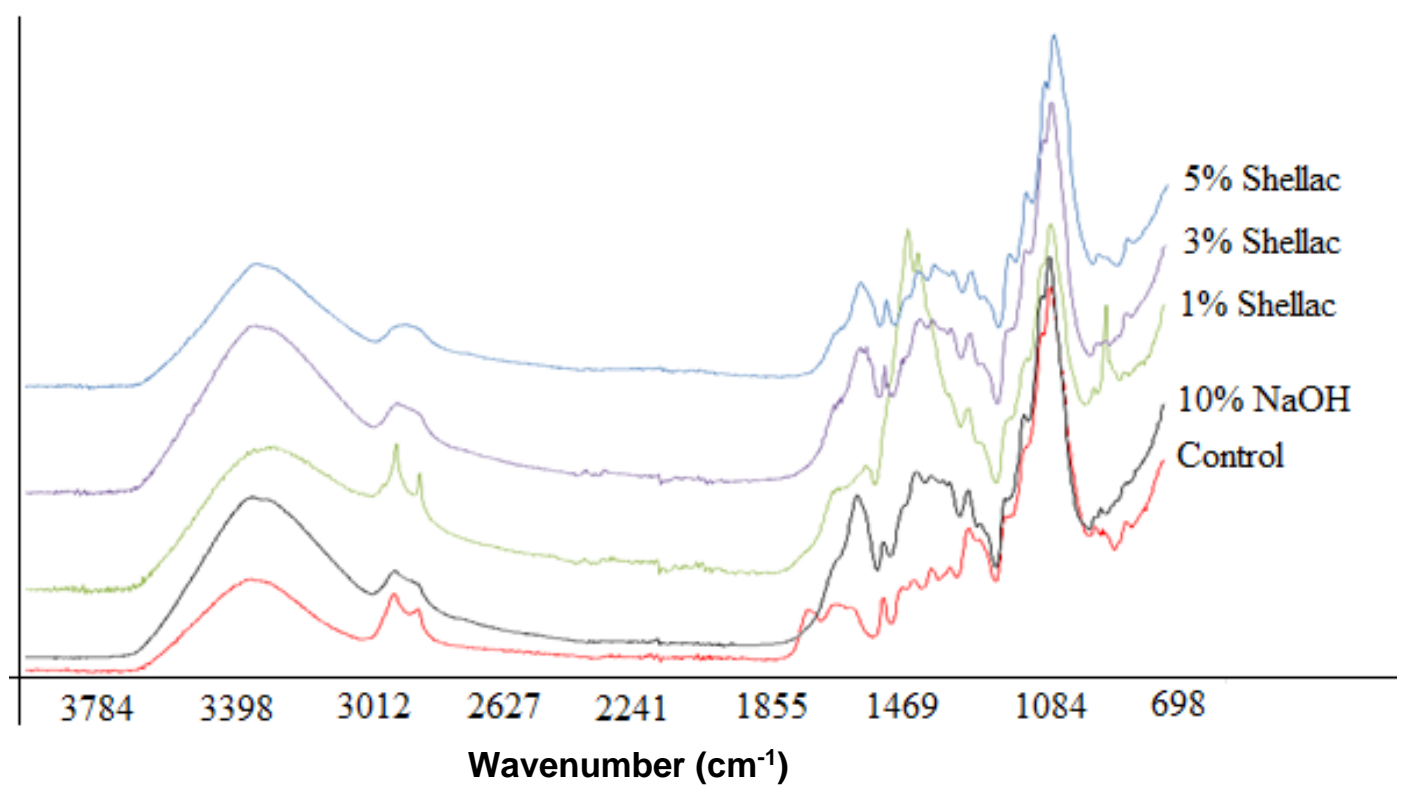

Fig. 4. FTIR spectra of Scots pine wood treated with $\mathrm{NaOH}$ and shellac and the untreated control 


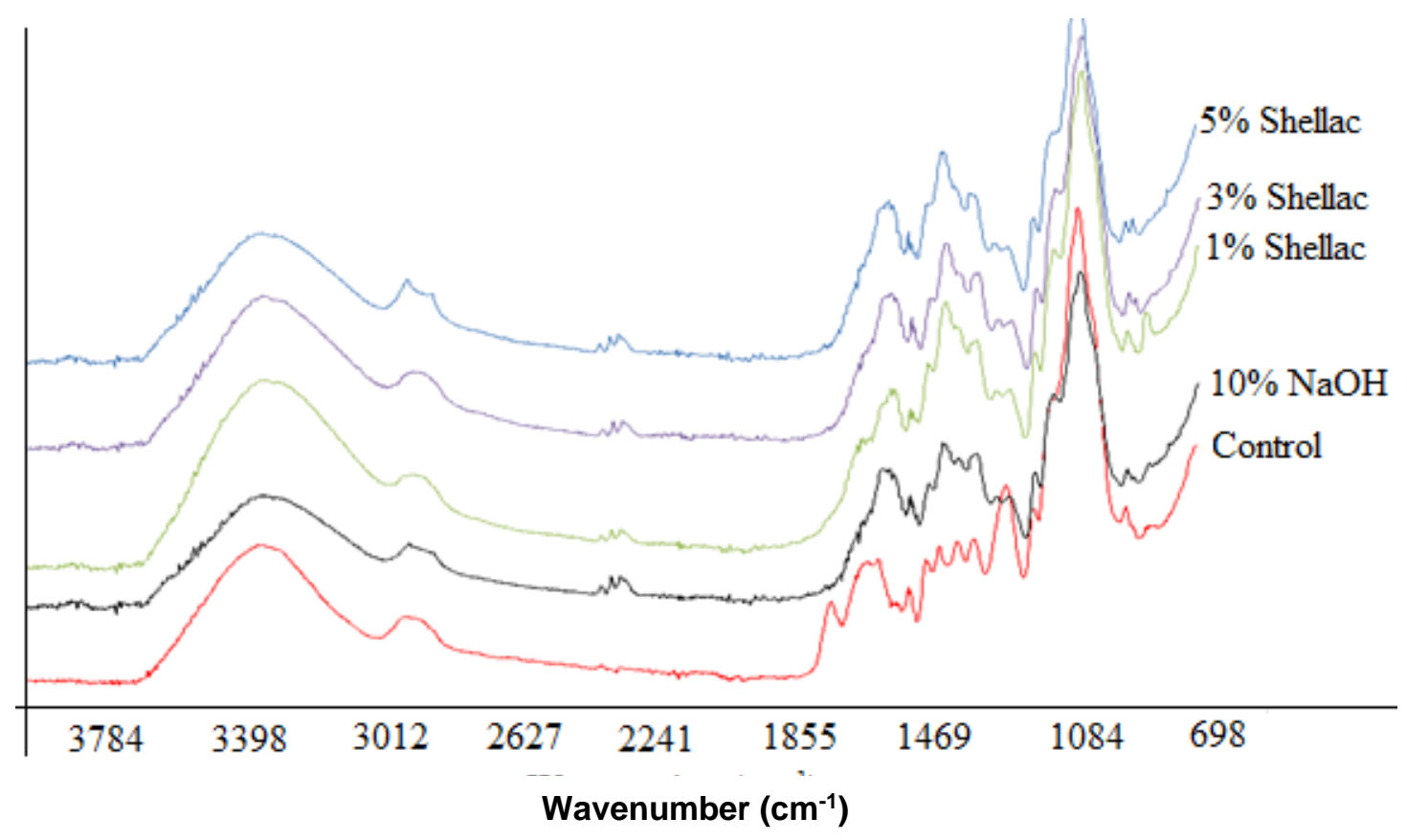

Fig. 5. FTIR spectra of beech wood treated with $\mathrm{NaOH}$ and shellac and the untreated control

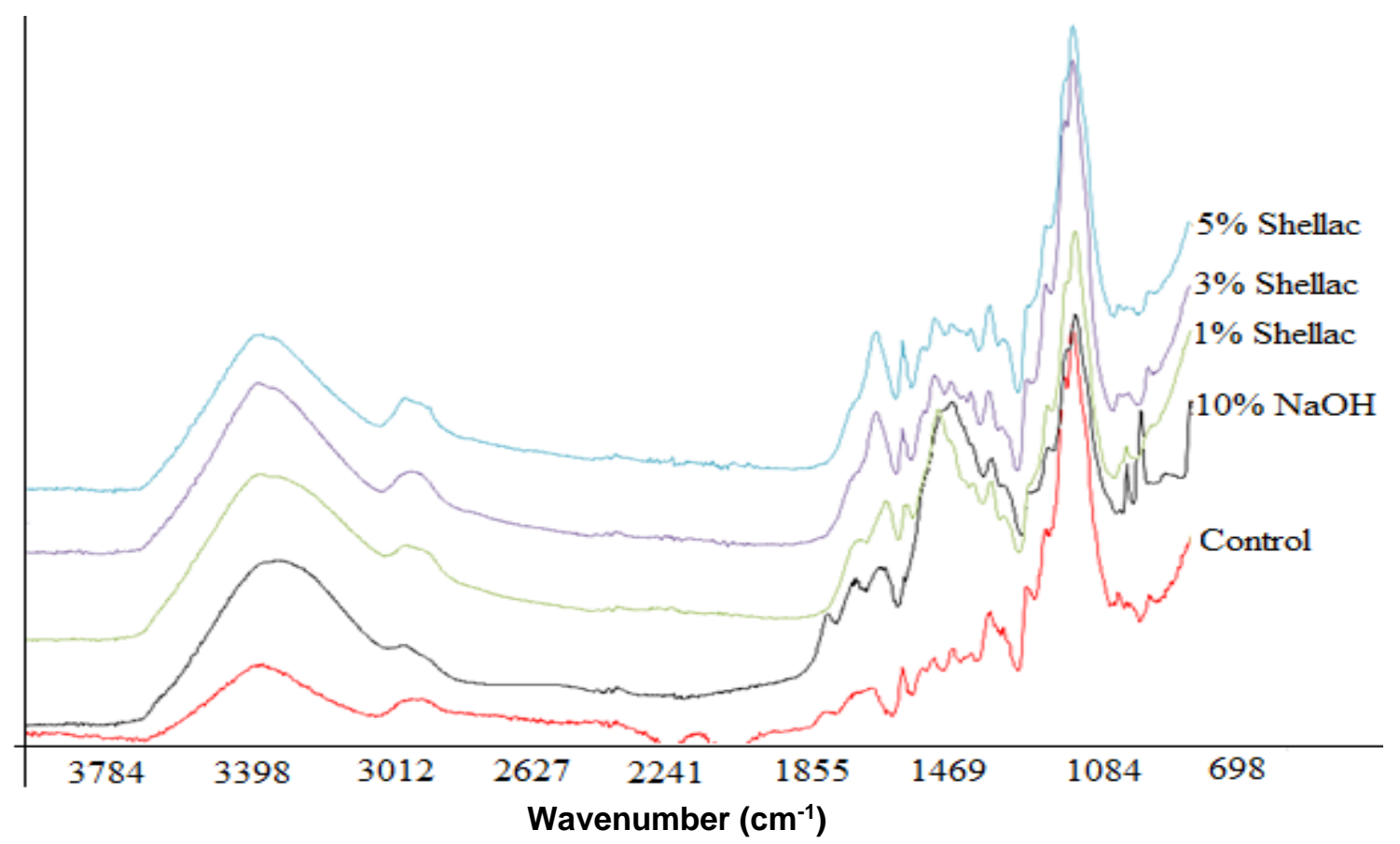

Fig. 6. FTIR spectra of the fir wood treated with $\mathrm{NaOH}$ and shellac and the untreated control

The absorbance peaks at 2928 and $2856 \mathrm{~cm}^{-1}$ were related to the $\mathrm{CH}_{2}$ stretching (asymmetric and symmetric, respectively). This peak value increased in the Scots pine samples impregnated with shellac at $1 \%$ concentration. In one study, it was noted that these peaks were characteristic of shellac (Ma et al. 2017). In this study, the $1734 \mathrm{~cm}^{-1}$ peak disappeared in all variations after the impregnation process. This band was specifically attributed to the stretching of free carbonyl groups such as xylan and glucomannan. The alkali treatment caused a peeling reaction of glucomannan and xylan that resulted in the 
disappearance of the peak density at $1734 \mathrm{~cm}^{-1}$ (Marchessault and Liang 1962). The peak at the $1579 \mathrm{~cm}^{-1}$ band appeared with the alkaline and shellac treatment of the woods. This band was attributed to aromatic skeletal vibration and had a higher absorbance peak for lignin. It can be said that shellac and sodium hydroxide do not cause significant changes in lignin absorbance values. The appearance of a lignin peak at $1579 \mathrm{~cm}^{-1}$ can be explained by the degradation of extractives, water soluble content, and xylan by the alkaline processing. Moreover, in another study, it was reported that sodium shellac gave a characteristic peak at $1560 \mathrm{~cm}^{-1}$ (Ma et al. 2017). The $1508 \mathrm{~cm}^{-1}$ peak shows the syringyl and guaiacyl elements found in lignin (Shi et al. 2012). The peak value decreased in the Scots pine samples after the impregnation process, while no change was observed in the beech samples. Although the $1504 \mathrm{~cm}^{-1}$ peak disappeared after the impregnation with $\mathrm{NaOH}$ in the fir wood samples, these peak values reappeared after the impregnation with shellac. The peak in the $1406 \mathrm{~cm}^{-1}$ band increased in all the wood species after the $\mathrm{NaOH}$ treatment. The rise in the peak value declined when the shellac concentration was increased. This peak $\mathrm{CH}_{2}$ scissoring motion implies that changes in the peak intensity were related to alterations in the environment of the C6 group (Liang and Marchessault 1959). Although the peak values around $1260 \mathrm{~cm}^{-1}$ due to absorptions in non-cellulosic polysaccharides (Michell 1992) increased in the Scots pine and fir samples, no change was observed in the beech wood samples. Significant decreases were obtained in the peak value, which appears at $1226 \mathrm{~cm}^{-1}$ in the beech wood samples and is associated with the $\mathrm{C}-\mathrm{OH}$ bending in the C6 plane (Gwon et al. 2010). The band at $897 \mathrm{~cm}^{-1}$ assigned as $\mathrm{C}-\mathrm{O}-\mathrm{C}$ asymmetric stretching (Schwanninger et al. 2004) for the Cell-I structure shifted to 835

$\mathrm{cm}^{-1}$ for the Cell-II structure with the $1 \%$ shellac impregnation in the Scots pine, to 860 $\mathrm{cm}^{-1}$ in the beech, and to $870 \mathrm{~cm}^{-1}$ in the fir wood

\section{CONCLUSIONS}

1. A good permeability was achieved after impregnation with the shellac solution, and the maximum weight gain values were obtained in the solution prepared at $1 \%$ concentration of shellac.

2. The bending strength values were reduced in the woods impregnated with shellac at $1 \%$ concentration. The reductions in the $10 \% \mathrm{NaOH}$ samples confirmed that the decreases were due to the $\mathrm{NaOH}$ used as the solution. It was thought that the use of $\mathrm{NaOH}$ in concentrations of less than $10 \%$ would limit the diminished mechanical properties.

3. The chemical structure of the wood samples exhibited significant changes after the impregnation with the $\mathrm{NaOH}$ at $10 \%$ concentration. In the samples impregnated with shellac, changes caused by the $\mathrm{NaOH}$ in the solution were observed in the wood. The fact that it is a natural polymer and is compatible with the host tree demonstrates that shellac can be used in wood preservation processes.

4. Future studies on shellac, such as reducing the $\mathrm{NaOH}$ concentration, using different solvents, determining the outdoor performance, and testing against insect and fungal effects, would further contribute to the literature. 


\section{REFERENCES CITED}

Bar, H., and Bianco-Peled, H. (2020). "Modification of shellac coating using Jeffamine ${ }^{\circledR}$ for enhanced mechanical properties and stability," Progress in Organic Coatings 141, 105559. DOI: 10.1016/j.porgcoat.2020.105559

Chandrasekar, M., Ishak, M. R., Sapuan, S. M., Leman, Z., and Jawaid, M. (2017). “A review on the characterisation of natural fibres and their composites after alkali treatment and water absorption," Plastics, Rubber and Composites 46(3), 119-136. DOI: 10.1080/14658011.2017.1298550

Chen, S., Xu, C., Mao, L., Liu, F., Sun, C., Dai, L., and Gao, Y. (2018). "Fabrication and characterization of binary composite nanoparticles between zein and shellac by antisolvent co-precipitation," Food and Bioproducts Processing 107, 88-96. DOI: 10.1016/j.fbp.2017.11.003

DIN 52186 (1978). "Testing of wood: Bending test," German Institute for Standardisation, Berlin, Germany.

Ghosh, M., Gupta, S., and Kumar, V. S. K. (2015). "Studies on the loss of gloss of shellac and polyurethane finishes exposed to UV," Maderas. Ciencia y tecnología 17(1), 39-44. DOI: 10.4067/S0718-221X2015005000004

Gwon, J. G., Lee, S. Y., Doh, G. H., and Kim, J. H. (2010). "Characterization of chemically modified wood fibers using FTIR spectroscopy for biocomposites," Journal of Applied Polymer Science 116(6), 3212-3219. DOI: 10.1002/app.31746

ISO 7724-2 (1984). "Paints and varnishes - Colorimetry - Part 2: Colour measurement," International Organization for Standardization, Geneva, Switzerland.

Isogai, A., and Atalla, R. H. (1998). "Dissolution of cellulose in aqueous $\mathrm{NaOH}$ solutions," Cellulose 5(4), 309-319. DOI: 10.1023/A:1009272632367

Janssen, J. J. (2000). "Designing and building with bamboo," International Network for Bamboo and Rattan. Netherlands.

Jankowska, A., and Szczęsna, M. (2011). "The study of colour changes of chosen species of wood from southeast asia caused by transparent coatings and exposure to sunlight," Drewno: Prace Naukowe, Doniesienia, Komunikaty 54, 51-59.

Kamperidou, V., Barboutis, I., and Vasileiou, V. (2014). "Influence of thermal treatment on mechanical strength of Scots pine (Pinus sylvestris L.) wood," Wood Research 59(2), 373-378.

Liang, C. Y., and Marchessault, R. H. (1959). "Infrared spectra of crystalline polysaccharides. II. Native celluloses in the region from 640 to $1700 \mathrm{~cm}^{-1}$, Journal of Polymer Science Part A: General Papers 39(135), 269-278. DOI: 10.1002/pol.1959.1203913521

Licchelli, M., Malagodi, M., Somaini, M., Weththimuni, M., and Zanchi, C. (2013). "Surface treatments of wood by chemically modified shellac," Surface Engineering, 29(2), 121-127. DOI: 10.1179/1743294412Y.0000000069

Liu, M., Tu, X., Liu, X., Wu, Z., Lv, J., and Varodi, A. (2020a). “A comparative study on the effects of linseed oil and shellac treatment on the hygroscopicity, dimensional stability, and color changes of Chinese ash wood," BioResources 15(4): 8085-8092. DOI: 10.15376/biores. 15.4.8085-8092

Liu, M., Xu, G., Wang, J., Tu, X., Liu, X., Wu, Z., Lv, J., and Xu, W. (2020b). “Effects of shellac treatment on wood hygroscopicity, dimensional stability and thermostability," Coatings 10(9), 881-890. DOI: 10.3390/coatings10090881

Luangtana-Anan, M., Soradech, S., Saengsod, S., Nunthanid, J., and Limmatvapirat, S. 
(2017). "Enhancement of moisture protective properties and stability of pectin through formation of a composite film: Effects of shellac and plasticizer," Journal of Food Science 82(12), 2915-2925. DOI: 10.1111/1750-3841.13956

Luo, Q., Li, K., Xu, J., Li, K., Zheng, H., Liu, L., and Sun, Y. (2016). "Novel biobased sodium shellac for wrapping disperse multiscale emulsion particles," Journal of agricultural and food chemistry 64(49), 9374-9380. DOI: 10.1021/acs.jafc.6b04417

Ma, K., Qiu, Y., Fu, Y., and Ni, Q.-Q. (2017). "Improved shellac mediated nanoscale application drug release effect in a gastric-site drug delivery system," RSC Advances 7(84), 53401-53406. DOI: 10.1039/C7RA10757A

Marchessault, R. H., and Liang, C. Y. (1962). "The infrared spectra of crystalline polysaccharides. VIII. Xylans," Journal of Polymer Science 59(168), 357-378. DOI: 10.1002/pol.1962.1205916813

Mei, S., Han, P., Wu, H., Shi, J., Tang, L., and Jiang, Z. (2018). “One-pot fabrication of chitin-shellac composite microspheres for efficient enzyme immobilization," Journal of Biotechnology 266, 1-8. DOI: 10.1016/j.jbiotec.2017.11.015

Michell, A. J. (1992). "FTIR spectroscopic studies of the reactions of wood and of lignin model compounds with inorganic agents," Wood Science and Technology 27(1), 6980. DOI: $10.1007 / \mathrm{BF} 00203412$

Obembe, O. O. (2006). "Bioengineering cellulose-hemicellulose networks in plants," Wageningen University and Research.

O'Neill, M. A., and York, W. S. (2018). "The composition and structure of plant primary cell walls," Annual Plant Reviews, online, 1-54.

Negawo, T. A., Polat, Y., Buyuknalcaci, F. N., Kilic, A., Saba, N., and Jawaid, M. (2019). "Mechanical, morphological, structural and dynamic mechanical properties of alkali treated Ensete stem fibers reinforced unsaturated polyester composites," Composite Structures 207, 589-597. DOI: 10.1016/j.compstruct.2018.09.043

Panov, D., Terziev, N., and Daniel, G. (2010). "Using plant oils as hydrophobic substances for wood protection," in: $41^{\text {st }}$ Annual Meeting of the International Research Group on Wood Protection Biarritz, France.

Pastore, T. C., Santos, K. O., and Rubim, J. C. (2004). "A spectrocolorimetric study on the effect of ultraviolet irradiation of four tropical hardwoods," Bioresource Technology 93(1), 37-42. DOI: 10.1016/j.biortech.2003.10.035

Patel, A. R., Remijn, C., Cabero, A. I. M., Heussen, P. C., ten Hoorn, J. W. S., and Velikov, K. P. (2013). "Novel all-natural microcapsules from gelatin and shellac for biorelated applications," Advanced Functional Materials 23(37), 4710-4718. DOI: 10.1002/adfm.201300320

Percin, O., Peker, H., and Atilgan, A. (2016). "The effect of heat treatment on some physical and mechanical properties of beech (Fagus orientalis Lipsky) wood," Wood Research 61(3), 443-456.

Reinprecht, L. (2011). "Possibilities for improvement of moisture and strength properties of decayed spruce wood with natural resins," Wood Research 56(3), 285-296.

Remadevi, O. K., Siddiqui, M. Z., Nagaveni, H. C., Rao, M. V., Shiny, K. S., and Ramani, R. (2015). "Efficacy of shellac-based varnishes for protection of wood against termite, borer and fungal attack," Journal of the Indian Academy of Wood Science 12(1), 9-14.

Ross, R. J. (2010). Wood Handbook: Wood as an Engineering material (FPL-GTR-190), U. S. Department of Agriculture Forest Product Laboratory, Madison, WI.

Schwanninger, M., Rodrigues, J. C., Pereira, H., and Hinterstoisser, B. (2004). "Effects 
of short-time vibratory ball milling on the shape of FT-IR spectra of wood and cellulose," Vibrational Spectroscopy 36(1), 23-40. DOI:

10.1016/j.vibspec.2004.02.003

Shi, J., Lu, Y., Zhang, Y., Cai, L., and Shi, S. Q. (2018). "Effect of thermal treatment with water, $\mathrm{H}_{2} \mathrm{SO}_{4}$ and $\mathrm{NaOH}$ aqueous solution on color, cell wall and chemical structure of poplar wood," Scientific Reports 8, 17735. DOI: 10.1038/s41598-01836086-9

Shi, J., Xing, D., and Lia, J. (2012). "FTIR studies of the changes in wood chemistry from wood forming tissue under inclined treatment," Energy Procedia 16(B), 758762. DOI: 10.1016/j.egypro.2012.01.122

Teng, T.-J., Arip, M. N. M., Sudesh, K., Nemoikina, A., Jalaludin, Z., Ng, E.-P., and Lee, H.-L. (2018). "Conventional technology and nanotechnology in wood preservation: A review," BioResources 13(4), 9220-9252. DOI: 10.15376/biores.13.4.Teng

Tiimonen, H. (2007). "Lignin characteristics and ecological interactions of PtCOMTmodified silver birch," Finnish Society of Forest Science.

Wang, Y., Zhao, Y., and Deng, Y. (2008). "Effect of enzymatic treatment on cotton fiber dissolution in $\mathrm{NaOH} /$ urea solution at cold temperature," Carbohydrate Polymers 72(1), 178-184. DOI: 10.1016/j.carbpol.2007.08.003

Wong, L. J., H'ng, P. S., Wong, S. Y., Lee, S. H., Lum, W. C., Chai, E. W., Wong, W. Z., and Chin, K. L. (2014). "Termite digestomes as a potential source of symbiotic microbiota for lignocelluloses degradation: A review," Pakistan Journal of Biological Sciences 17(8), 956-963. DOI: 10.3923/pjbs.2014.956.963

Yan, X., Tao, Y., and Chang, Y. (2021). "Effect of shellac waterborne coating microcapsules on the optical, mechanical and self-healing properties of waterborne primer on Tilia europaea L. wood," Coatings 11(7), 785-802. DOI: 10.3390/coatings11070785

Yin, J., Yuan, T., Lu, Y., Song, K., Li, H., Zhao, G., and Yin, Y. (2017). “Effect of compression combined with steam treatment on the porosity, chemical composition and cellulose crystalline structure of wood cell walls," Carbohydrate Polymers 155 , 163-172. DOI: 10.1016/j.carbpol.2016.08.013

Zeidler, A., Salem, M. Z. M., and Borůvka, V. (2015). "Mechanical properties of grand fir wood grown in the Czech Republic in vertical and horizontal positions," BioResources 10(1), 793-808.

Article submitted: November 14, 2021; Peer review completed: January 15, 2022;

Revised version received and accepted: January 19, 2022; Published: January 21, 2022.

DOI: 10.15376/biores.17.1.1703-1716 